\title{
Financial Stability Report: Lessons from the Central Banks
}

\author{
Filali Adib Fatine \\ University Mohammed V \\ Faculty of law, economic and social sciences of Souissi \\ Firano Zakaria \\ University Mohammed V Rabat \\ Faculty of law, economic and social sciences of Rabat-Agdal
}

\begin{abstract}
The economic and social costs of the financial crises are very high led the central banks to register financial stability, in addition to the price stability, in the middle of their concerns. Nevertheless, the objectives of the central banks as regards financial stability are less clear and specific that in the monetary field. This difficulty related to the abstract character and multidimensional of the concept of financial stability makes difficult to quantify an objective, to check the realization of it and complicates the communication strategy to be adopted on the matter. In spite of these difficulties, the central banks reinforced their communications as regards financial stability by the publication of Financial Stability Report (FSR). The latter describe the various risks overall weighing on the stability of the financial system and formulate a judgment on its impact strength and its capacity to reabsorb the various potential shocks. The RSF aim reinforcing the transparency on the various components of the financial system and at supporting the emergence of a framework of co-operation between the various speakers. Vis-a-Vis the stakes of financial stability, the majority of the central banks widened their missions with the maintenance of financial stability. In the same way, they recorded signification advances in the installation of the framework of financial stability (institutional, lawful, and operational). Within this framework, this paper tries to describe the practices of the central banks as regards development of the FSR and formula of the recommendations aiming at proposing an exhaustive analysis of the FSR. Initially, it presents the objectives sought through this communication strategy and examines, without going into the details, the structure adopted in the development of the RSF.
\end{abstract}

Keywords: Financial stability, systemic risk, macro stress test, financial soundness indicators. JEL classification: E44, D42

\section{INTRODUCTION}

Well before the international financial crisis of 2007-2008, several central banks were interested in financial stability in answer to the increase in the banking crises and their securities on the good being of the economic agents. This increased interest materialized primarily through the publication of the financial stability Report, recalling the evolutions of the financial systems and systemic risks. During this period, the analysis of the financial system was regarded as one of the fundamental missions of the Central banks in bond primarily with their roles of monetary authorities and supervisors of the money markets, the banking institutions and the payment systems. 
The lesson drawn from the recent crisis gave more dash to this practice because of the new role of the central bank as regards financial stability. From now on, the monetary authorities must contribute, according to various methods, to the prevention of the systemic risks and the maintenance of the good performance of the financial system. For this purpose, the new macroprudential instruments were placed at their disposal to guarantee the impact strength of the financial system and to reduce its procyclicality.

The FRS make it possible to follow and analyze the risks and the possible transmission channels of the shocks affecting the financial system, in order to guard itself against the systemic crises. The difference in the other report (on the banking supervision and the systems of payment, etc.), the latter analyze the systemic risks, to identify the areas of vulnerability and to as a whole evaluate the degree of impact strength of the financial system (a macroprudential monitoring).

The examination of the Central banks experiments as regards development of the FSR reveals that until now no consensus was established with regard to the structure of these reports and even less for the tools and the indicators to be used. The difficulty in sitting the best-practices on the matter is the principal consequence of the difficulty of determining with precision the concept of financial stability and of the structures very different from the financial systems.

This paper, structured in five sections, aims to describe the practices of the central banks as regards development of the financial stability report. First of all, it presents the factors influencing the decision to publish a FSR and the objectives sought through this communication strategy. Then, it examines the structure commonly adopted in the development of the FSR. Thereafter, it presents the indicators used in these reports. Lastly, a last point was devoted to the examination of the place of the stresses tests and the macro stresses testing in these reports, like new tools for evaluation of the risks of financial instability.

\section{WHO PUBLISHES THE FSR?}

The evaluation of financial stability implies the monitoring continues and the risk analysis and of the vulnerabilities potentials weighing on the financial system. This evaluation facilitates the formulation of a judgment on the degree of impact strength of the financial system which can be communicated with the general public in order to allow a better evaluation of the risk and an efficient management of economic anticipations. Among the approaches of communication at the disposal of the central banks, the publication of the Reports of Financial stability occupies an important place.

Several central banks started to publish FSR in the objective to limit the phenomena of financial instability by informing the Government, the institutions financial and not - financial, the markets and the general public on the principal risks and vulnerabilities. Although the current crisis stimulated the publication of these reports, the number of countries having already published a FSR remains limited.

The first attempt at publication of RSF was that of the Bank of England in 1997, after the fall of several banks (Bank of the Credit and International business (BCCI) in 1991 and Barings in 1995). Then, several Scandinavian countries having lived difficulties similar to the level of their banking sectors (Finland (1991-1994), Norway (1987-1993) and Sweden (1990-1993)) borrowed the same way. 
This attempt at publication of the FSR was reinforced after the advent of the international financial crisis because primarily of attribution at the central banks of a new mission of financial stability centered mainly on the macro-prudential regulation. According to the study of Cihak and Al. (2012), on a total of 177 countries, 84 countries published RSF in 2011 compared to 60 in 2006. This increase confirms the fact that the publication of the RSF is often stimulated by the advent of the financial crises and banking. Indeed, the countries having lived banking crises were precursory in the development of the FSR in order to be guarded against future crises (for example Asian and other countries and of the Latin America).

In the same way, the analysis of the relation between the decision to publish a RSF and the advent of the banking crises shows that the countries having lived crises were most active as regards publication of these reports. Thus, on 102 countries which lived a crisis, more than $50 \%$ already their RSF communicated. On the other hand, on the 75 countries which were not touched by a banking crisis $42 \%$ only published their reports.

\begin{tabular}{cccc}
\hline \multicolumn{4}{c}{ Tableau 1 : relation between publication of the FSR and crises banking } \\
\hline The countries which: & Not crisis & Crisis & Total \\
& 43 & 50 & 93 \\
Publish & 32 & 52 & 84 \\
& 75 & 102 & 177 \\
\hline
\end{tabular}

In addition to the banking experiments of crises, other factors in particular related to the level of development of the countries condition the decision of publication of the FSR. Thus and according to the analysis of the country constituting our sample, it arises that among the countries having published a FSR more than 44\% are developed nations, 19\% are emergent countries and $31 \%$ of the countries are in the developing. On the other hand, the sample of the countries which did not choose the publication of the RSF yet is mainly composed of the economies under development and with weak development (Figures 1).

Countries not publish the FSR

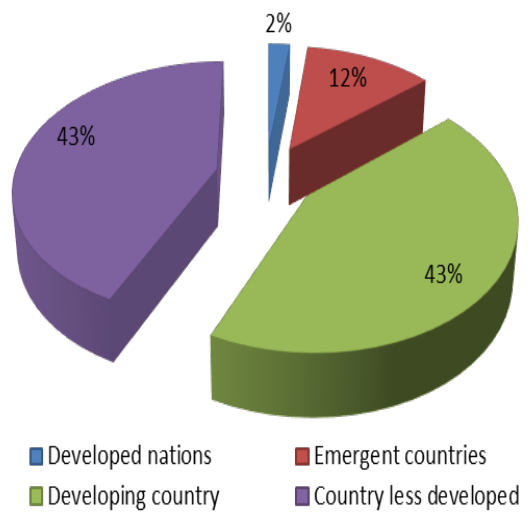

Countries publishing the FSR

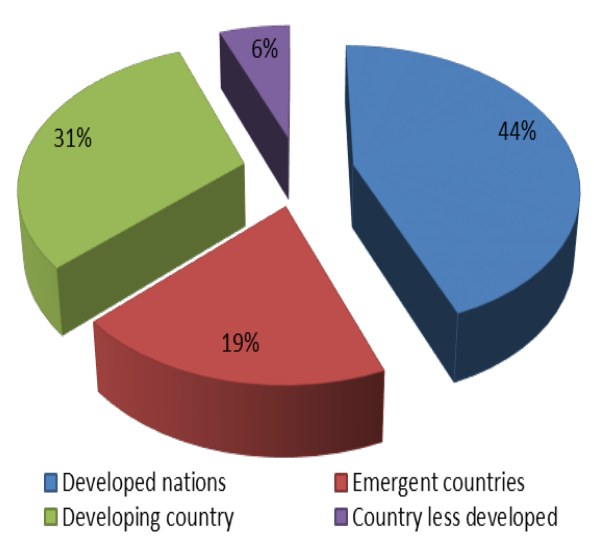

Figure 1. FSR and level of development

On the same register, on 39 developed nations more than $94 \%$ already their FSR communicated. As for the emergent countries, $60 \%$ published their FSR. On the other hand, the analysis of the developing countries and those with weak development indicate that the majority of them did not publish reports of financial stability yet (see table hereafter). 
Tableau 2 : FSR publication according to the level of development of the countries

\begin{tabular}{cccccc}
\hline Publication & $\begin{array}{c}\text { Developed } \\
\text { nations }\end{array}$ & $\begin{array}{c}\text { Emergent } \\
\text { countries }\end{array}$ & $\begin{array}{c}\text { Country sees } \\
\text { development of } \\
\text { it }\end{array}$ & $\begin{array}{c}\text { Country } \\
\text { with low- } \\
\text { income }\end{array}$ & Total \\
Publish & $\mathbf{2}$ & $\mathbf{1 1}$ & $\mathbf{4 0}$ & $\mathbf{4 0}$ & $\mathbf{9 3}$ \\
& $\mathbf{3 7}$ & $\mathbf{1 6}$ & $\mathbf{2 6}$ & $\mathbf{5}$ & $\mathbf{8 4}$ \\
& $\mathbf{3 9}$ & $\mathbf{2 7}$ & $\mathbf{6 6}$ & $\mathbf{4 5}$ & $\mathbf{1 7 7}$ \\
\hline
\end{tabular}

In addition, the publication of the RSF is also explained by the size of the financial system. The countries having developed financial systems are brought to produce FSR than those whose financial system is less dominating. Indeed, for the countries having already published FSR the credit to GDP ratio is close to $100 \%$. On the other hand, the countries which did not publish a RSF yet have an average ratio from approximately $48 \%$ (table 3 ).

\begin{tabular}{ccc}
\hline \multicolumn{2}{c}{ Tableau 3: } & FSR publication according to the level of financial development \\
\hline Group country & Number & Average Credit to GDP in \% \\
Do not publish & 67 & 48 \\
\hline
\end{tabular}

At the regional level, the publication of the RSF is largely widespread on the level of Europe, Asia and the Latin America. The majority of the countries of these areas communicated FSR well before the international financial crisis. It is not that after the fall of Lehman Brothers that the United States and more than 20 other countries published their FSR. Africa and the MiddleEast remain late as regards publication of the FSR. Indeed, to the level of the area only some countries already published their FSR. It is about Jordan (2010), Bahrain (2007), Qatar (2009) and recently Oman (2013) and Morocco (2015). With regard to the African continent, South Africa (2004), Ghana (2005), Kenya (2004), Uganda (2009) and the Central Bank of the States of West Africa (BCEAO, 2006) overall communicated their RSF before the advent of the international financial crisis.

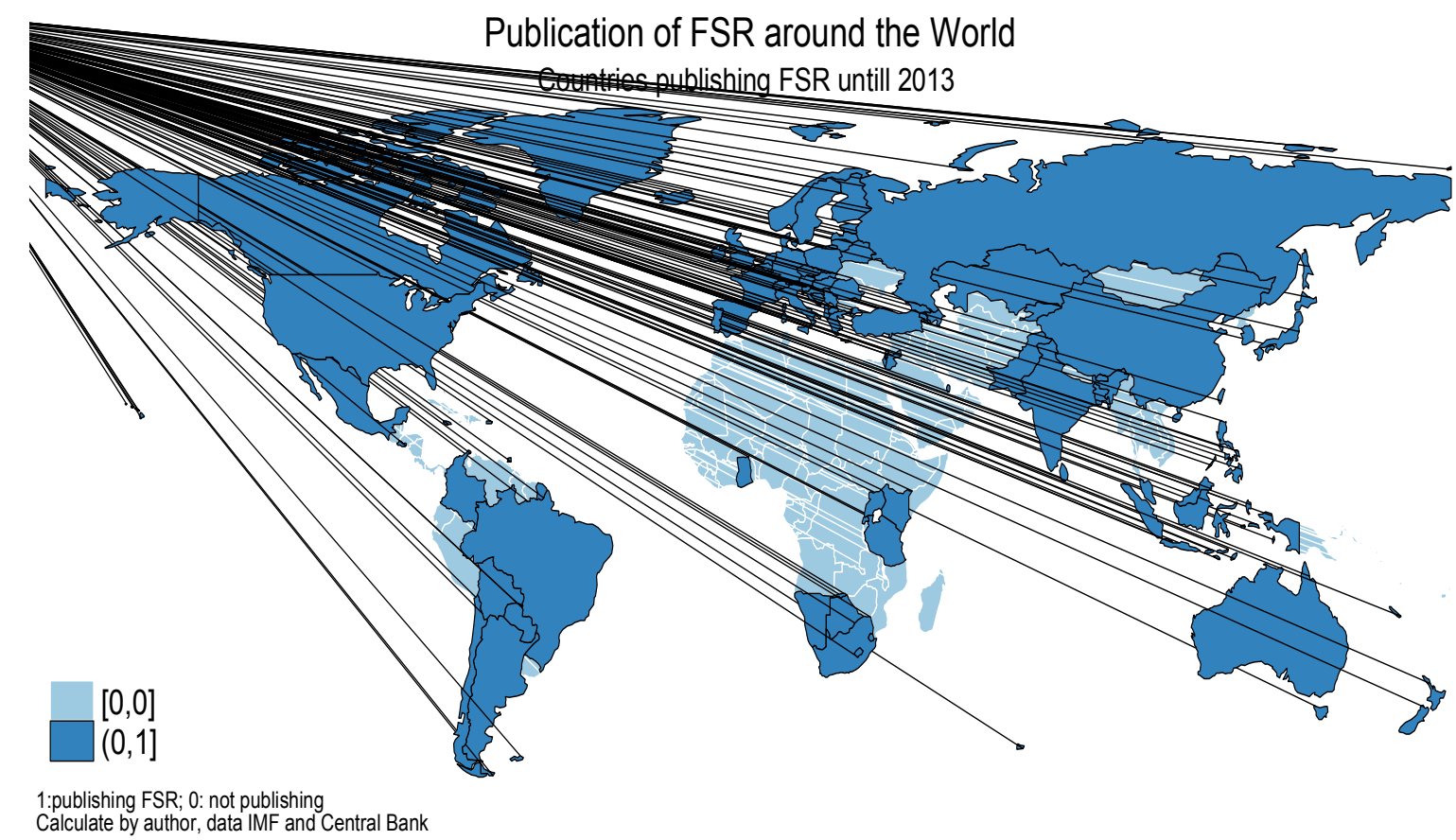




\section{WHY PUBLISH A FSR?}

The publication of the FSR, according to Svensson (2003), aims at informing the public and the economic actors on health of the financial system and constitutes an instrument of early alarm for the agents concerned and the regulatory agencies financial when problems are profiled at the horizon. In general, three aims are had by the publication of the FSR. It makes it possible to contribute to the total stability of the financial system, reinforces the responsibility, the credibility and the transparency of the central banks and supports the cooperation between the various authorities implied in the maintenance of financial stability.

To contribute to the total stability of the financial system. The regular analysis of the financial market evolution and the identification of the risks support the early detection of the potential threats and thus the adoption of precautionary measures (macro-prudential) and corrective (management of the crises) suitable. Also, by informing the public on the state of the financial system, the publication of the FSR thus facilitates decision making in terms of macroprudential policies and management of the crises and contributes, consequently, with the stability of the financial system. This objective is transcribed clearly in one of the FSR of the Central Bank of Austria (2001) "Central Bank decided to regularly publish a report on financial stability in order to inform all the actors of the financial markets and the general public on the problems which could occur in the event of distress".

To reinforce the transparency, the credibility and the financial responsibilities of the regulatory agencies. As regards financial stability, the responsibility for the authorities in charge of this mission is closely related to their capacity to explain and justify the utilization of macro prudential (preventive and corrective) firms through an attentive examination of the areas of risk and transmission channels of the shocks. Thus, the transparency on the evolutions of the financial system and the established judgment, is essential in order to guarantee a better comprehension and transmission of the decisions of the macro-prudential policies and consequently to sit occasion credibility as regards maintenance of financial stability (Lastra (2001)).

To strengthen the cooperation between the various authorities on the questions of financial stability. According to the National Bank of Belgium (2002), the FSR aims stimulating not only the debate on the risks and the vulnerabilities, but also, at contributing to the reinforcement of the cooperation between the authorities in charge of financial stability. This cooperation develops as well on the national plan as international and regional. Indeed, at the national level, the publication of the FSR makes it possible to inform the unit of the regulatory agencies on the situation of the financial system and the relevance of the decisions to be discussed and implement at resulting from the meetings from the national committees (management board of the crises, systemic committee risks). In the same way, the development of the RSF supports the international cooperation through the identification of the risks on the level of each country. This analysis makes it possible the other countries to evaluate their cross-border exhibitions and to limit the contagion and the probability of supervening of international financial crisis.

In addition to these three objectives, the FSR also contributes to reinforce the micro-prudential monitoring and the control of the monetary policy. Although this report have a systemic orientation, the analysis which it provides is capable to identify the areas of vulnerabilities likely to be examined by the supervision authorities in order to limit the probability of supervening of the systemic crises. In the same way, the analyzes carried out on the level of the FSR in particular make it possible to look further into the comprehension of the economic conditions and financial, important dimension in decision making as regards monetary policy. 


\section{HOW TO STRUCTURE A FSR?}

Although the structure of the FSR varies from one country to another, it remains generally made up of two great parts. The first, constituting the hard core of the report, is interested in the examination of the risks and the vulnerabilities of the financial system and in the evaluation of its degree of impact strength to the shocks. It is articulated around several axes. First of all, the national and international macroeconomic and financial environment is analyzed. Then, this part treats domestic market evolutions financial, infrastructures of market and financial and not - financial institutions. Moreover, it presents an evaluation of the degree of impact strength of the financial system and in particular of the banking sector vis-a-vis the macroeconomic and financial shocks most plausible. The second part of FSR, as for it, is primarily made up of items and special issues treating of the related questions with financial stability and of private interest for the monetary authorities (BIS, Comity I. Fisher (2005)).

In the majority of the FSR, the first part accounts for approximately $2 / 3$ of the total contents. Certain countries like France reserve only the $1 / 3$ to him, whereas others devote the totality of the report to him, as it is the case for Norway.

The first part of the FSR is structured in order to describe the process of evaluation of financial stability. Several indicators are used within this framework in order to identify the areas of vulnerability. These last can rise from unfavorable macroeconomic conditions, a particular economic sector or exogenous shocks coming from the foreign financial markets. They can also emanate from an imbalance of the financial markets or brittleness of the financial institutions.

The analysis of the macroeconomic conditions makes it possible to identify the negotiable instruments of an economic contraction on the stability of the financial system. In this respect, an economic recession or a sectorial imbalance can involve a rise of the defects of the economic agents and affect consequently the solvency of the financial institutions and the assets value. Also, the foreign or international expositions can also have significant negotiable instruments on financial stability because of the potential interconnections between the various financial markets and of the increasingly important integration of the economies. In the same way, the existence of financial institutions and not-financial operating in several countries contributes to amplify the importance of the cross-border risks.

The risks emanating of the financial sector can come from the idiosyncratic or systemic problems relative to financial expositions, difficult conditions on the capital market or the weaknesses in the infrastructure of the markets. Thus, the default of a systemic financial institution or a large debtor can cause a stop of the transactions on the markets and result in a strong financial instability. Also, the existence of instability phenomena, in particular the financial bubbles, can increase the probability of materialization of systemic risk. In addition, other risks can result from the infrastructure of market and in particular from the payment and settlement systems.

Thus, the first part of the FSR aims at the examination of three axes: first milked with the analysis of the sources of international vulnerabilities, second is intended for the examination of the endogenous macroeconomic conditions, while the last is capable to evaluate the risks emanating of the financial system. 


\begin{tabular}{|c|c|c|c|c|c|c|c|c|}
\hline \multirow{2}{*}{$\begin{array}{c}\begin{array}{c}\text { Central } \\
\text { bank }\end{array} \\
\text { Central } \\
\text { Bank } \\
\text { European }\end{array}$} & \multirow{2}{*}{$\begin{array}{c}\text { Frequen } \\
\text { cy }\end{array}$} & \multicolumn{7}{|c|}{ Contents of the report/ratio: starts from each section (in \%) } \\
\hline & & $\begin{array}{c}\text { - Outline } \\
\text { of the } \\
\text { risks } \\
\text { weighing } \\
\text { on } \\
\text { financial } \\
\text { stability } \\
\mathbf{( 5 \% )}\end{array}$ & $\begin{array}{c}\text { - Macro- } \\
\text { financial } \\
\text { Environmen } \\
\text { t (27\%) }\end{array}$ & $\begin{array}{c}- \\
\text { Financial } \\
\text { system of } \\
\text { the Euro } \\
\text { area } \\
\mathbf{( 3 8 \% )}\end{array}$ & $\begin{array}{c}\text { - Specific } \\
\text { Area } \\
\mathbf{( 2 4 \% )}\end{array}$ & & & \\
\hline $\begin{array}{l}\text { Bank of } \\
\text { England }\end{array}$ & $\begin{array}{l}\text { Semi- } \\
\text { annual }\end{array}$ & $\begin{array}{l}\text { - Outline } \\
\mathbf{( 1 0 \% )}\end{array}$ & $\begin{array}{c}\text { - Risk credit } \\
\mathbf{( 2 4 \% )}\end{array}$ & $\begin{array}{l}\text { - Risks } \\
\text { related to } \\
\text { the } \\
\text { internatio } \\
\text { nal } \\
\text { financial } \\
\text { system } \\
\mathbf{( 1 1 \% )}\end{array}$ & $\begin{array}{l}\text { - Impact } \\
\text { strength of } \\
\text { the British } \\
\text { financial } \\
\text { system } \\
\mathbf{( 6 \% )}\end{array}$ & $\begin{array}{l}\text { - Solidity } \\
\text { of the } \\
\text { infrastruct } \\
\text { ures of the } \\
\text { financial } \\
\text { market }\end{array}$ & $\begin{array}{l}\text { - Items } \\
\mathbf{( 4 0 \% )}\end{array}$ & \\
\hline Riksbank & $\begin{array}{l}\text { Semi- } \\
\text { annual }\end{array}$ & $\begin{array}{c}- \\
\text { Foreword } \\
+ \\
\text { Summari } \\
\text { zed } \\
(\mathbf{1 5 \% )}\end{array}$ & $\begin{array}{l}\text { Evaluation } \\
\text { of stability }\end{array}$ & $\begin{array}{c}- \\
\text { Financial } \\
\text { market } \\
\text { and price } \\
\text { of the real } \\
\text { estate } \\
(11 \%)\end{array}$ & $\begin{array}{l}\text { Them } \\
\text { borrowers } \\
\text { of the } \\
\text { Swedish } \\
\text { banks } \\
(15 \%)\end{array}$ & $\begin{array}{c}- \\
\text { Developm } \\
\text { ent of the } \\
\text { banks } \\
(11 \%)\end{array}$ & $\begin{array}{c}\text { The } \\
\text { financial } \\
\text { infrastruct } \\
\text { ures }(14 \%)\end{array}$ & Items $(34 \%)$ \\
\hline $\begin{array}{c}\text { Bank of } \\
\text { Spain }\end{array}$ & $\begin{array}{l}\text { Semi- } \\
\text { annual }\end{array}$ & $\begin{array}{c}- \\
\text { Introducti } \\
\text { on } \mathbf{( 1 6 \% )}\end{array}$ & $\begin{array}{l}\text { - Chapter I: } \\
\text { Banking } \\
\text { risks } \mathbf{( 3 5 \% )}\end{array}$ & $\begin{array}{c}\text { - Chapter } \\
\text { II: } \\
\text { Profitabili } \\
\text { ty }(\mathbf{1 4 \% )})\end{array}$ & $\begin{array}{l}\text { - Chapter } \\
\text { III: } \\
\text { Solvency } \\
(\mathbf{1 2 \% )}\end{array}$ & $\begin{array}{l}\text { - Items and } \\
\text { glossary } \\
\mathbf{( 2 2 \% )}\end{array}$ & & \\
\hline $\begin{array}{l}\text { Banque } \\
\text { de } \\
\text { France }\end{array}$ & $\begin{array}{l}\text { Semi- } \\
\text { annual }\end{array}$ & $\begin{array}{c}- \\
\text { Summary } \\
(\mathbf{3 \% )}\end{array}$ & $\begin{array}{l}\text { - Economic } \\
\text { environment } \\
\text { And } \\
\text { International } \\
\text { Financier } \\
\mathbf{( 1 5 \% )}\end{array}$ & $\begin{array}{c}\text { Financial } \\
\text { sector } \\
(\mathbf{2 0} \%)\end{array}$ & $\begin{array}{l}\text { - Items } \\
\mathbf{( 5 5 \% )}\end{array}$ & & & \\
\hline $\begin{array}{c}\text { Bundesba } \\
\text { nk }\end{array}$ & Annual & $\begin{array}{l}\text { - Outline } \\
\mathbf{( 5 \% )}\end{array}$ & $\begin{array}{c}- \\
\text { Macroecono } \\
\text { mic } \\
\text { Prospects } \\
\text { and risk } \\
\text { factors }(\mathbf{9 \% )}\end{array}$ & $\begin{array}{c}- \\
\text { Internatio } \\
\text { nal } \\
\text { Financial } \\
\text { system } \\
\mathbf{( 2 5 \% )}\end{array}$ & $\begin{array}{c}\text { - Financial } \\
\text { Intermedia } \\
\text { ries in } \\
\text { Germany } \\
\mathbf{( 2 5 \% )}\end{array}$ & $\begin{array}{c}- \\
\text { Regulation } \\
\text { framework } \\
\text { and } \\
\text { infrastruct } \\
\text { ures of the } \\
\text { financial } \\
\text { market } \\
\mathbf{( 1 3 \% )}\end{array}$ & $\begin{array}{c}\text { - Appendix } \\
\mathbf{( 6 \% )}\end{array}$ & \\
\hline $\begin{array}{l}\text { Bank of } \\
\text { Canada }\end{array}$ & $\begin{array}{l}\text { Semi- } \\
\text { annual }\end{array}$ & $\begin{array}{c}\text { - Outline } \\
\text { + Raised } \\
\text { Problems } \\
\quad(\mathbf{2 0} \%)\end{array}$ & $\begin{array}{c}\text { - Macro- } \\
\text { financial } \\
\text { Environmen } \\
\text { t (8\%) }\end{array}$ & $\begin{array}{l}\text { Tendenci } \\
\text { es of the } \\
\text { financial } \\
\text { system } \\
\mathbf{( 1 3 \% )}\end{array}$ & $\begin{array}{c}- \\
\text { Reports/rat } \\
\text { ios (15\%) }\end{array}$ & $\begin{array}{c}\text { - Policies } \\
\text { and } \\
\text { developme } \\
\text { nt of the } \\
\text { infrastruct } \\
\text { ures }(\mathbf{1 5 \% )}\end{array}$ & $\begin{array}{l}\text { - Summary } \\
\text { of the } \\
\text { research } \\
\text { tasks }\end{array}$ & \\
\hline $\begin{array}{l}\text { Bank of } \\
\text { China }\end{array}$ & $\begin{array}{l}\text { Semi- } \\
\text { annual }\end{array}$ & $\begin{array}{c}- \\
\text { Summary } \\
\mathbf{( 7 \% )}\end{array}$ & $\begin{array}{c}\text { - Regional } \\
\text { and world } \\
\text { Context } \\
(\mathbf{3 0 \% )}\end{array}$ & $\begin{array}{c}\text { - Cost } \\
\text { savings } \\
\text { domestica } \\
\text { te } \mathbf{( 2 5 \% )}\end{array}$ & $\begin{array}{c}\text { - Financial } \\
\text { sector and } \\
\text { monetarist } \\
(\mathbf{2 0 \% )}\end{array}$ & $\begin{array}{c}- \\
\text { Prospects, } \\
\text { risks and } \\
\text { uncertainti } \\
\text { es }(\mathbf{1 6 \% )}\end{array}$ & & \\
\hline $\begin{array}{l}\text { Federal } \\
\text { fund }\end{array}$ & Annual & $\begin{array}{l}\text { - Outline } \\
\text { (7\%) }\end{array}$ & $\begin{array}{c}- \\
\text { Developmen } \\
t \text { of the } \\
\text { banking } \\
\text { balance- } \\
\text { sheets } \\
(\mathbf{2 8 \%}) .\end{array}$ & $\begin{array}{c}- \\
\text { Tendenci } \\
\text { es of } \\
\text { profitabili } \\
\text { ty and the } \\
\text { banking } \\
\text { risks } \\
(\mathbf{2 1 \% )}\end{array}$ & $\begin{array}{c}- \\
\text { Internation } \\
\text { al } \\
\text { Operations } \\
\text { of the } \\
\text { American } \\
\text { trade banks } \\
(\mathbf{0 . 5 \% )}\end{array}$ & $\begin{array}{c}\text { - Recent } \\
\text { Developm } \\
\text { ents } \\
\mathbf{( 0 . 5 \% )}\end{array}$ & $\begin{array}{c}- \\
\text { Appendice } \\
\text { s (43\%) }\end{array}$ & \\
\hline $\begin{array}{c}\text { Bank of } \\
\text { Japan }\end{array}$ & Annual & $\begin{array}{c}- \\
\text { Summary }\end{array}$ & $\begin{array}{l}- \\
\text { Developmen } \\
t \text { of the } \\
\text { profits and } \\
\text { the Balance- } \\
\text { sheet of the } \\
\text { Japanese } \\
\text { Banks (5\%) }\end{array}$ & $\begin{array}{l}\text { - Progress } \\
\text { in order } \\
\text { to } \\
\text { eliminate } \\
\text { the risks } \\
\mathbf{( 1 4 \% )}\end{array}$ & $\begin{array}{l}\text { Evaluation } \\
\text { of the risk } \\
\text { related to } \\
\text { the wallet } \\
\text { of the } \\
\text { assets } \\
\mathbf{( 7 \% )}\end{array}$ & $\begin{array}{c}- \\
\text { Profitabilit } \\
\text { y (9\%) }\end{array}$ & $\begin{array}{l}\text { - Stakes } \\
\text { for the } \\
\text { future } \\
\mathbf{( 4 \% )}\end{array}$ & \\
\hline $\begin{array}{l}\text { Central } \\
\text { Bank of } \\
\text { Turkey }\end{array}$ & $\begin{array}{l}\text { Semi- } \\
\text { annual }\end{array}$ & $\begin{array}{c}\text { - Outline } \\
(\mathbf{3} \%)\end{array}$ & $\begin{array}{c}\text { International } \\
\text { expansion } \\
(7 \%)\end{array}$ & $\begin{array}{c}\text { - Cost } \\
\text { savings } \\
\text { domestica } \\
\text { te }(19 \%)\end{array}$ & $\begin{array}{l}\text { - Risk and } \\
\text { developme } \\
\text { nt of the } \\
\text { banking } \\
\text { system } \\
(22 \%)\end{array}$ & $\begin{array}{l}\text { Financial } \\
\text { infrastruct } \\
\text { ure }(11 \%)\end{array}$ & $\begin{array}{l}\text { - Particular } \\
\text { Subjects } \\
(17 \%)\end{array}$ & \\
\hline
\end{tabular}

Copyright (C) Society for Science and Education, United Kingdom 


\begin{tabular}{|c|c|c|c|c|c|c|c|c|}
\hline $\begin{array}{c}\text { Central } \\
\text { Bank of } \\
\text { Chile }\end{array}$ & $\begin{array}{l}\text { Semi- } \\
\text { annual }\end{array}$ & $\begin{array}{c}- \\
\text { Summary } \\
(3 \%)\end{array}$ & $\begin{array}{c}\text { - External } \\
\text { Environmen } \\
\mathrm{t} \text { and } \\
\text { financial } \\
\text { risks }(9 \%)\end{array}$ & $\begin{array}{c}\text { - External } \\
\text { Financing } \\
\text { : flow of } \\
\text { capital } \\
\text { and } \\
\text { foreign } \\
\text { debt }(5 \%)\end{array}$ & $\begin{array}{l}\text { - Local } \\
\text { Financial } \\
\text { market } \\
(5 \%)\end{array}$ & $\begin{array}{l}\text { - Users of } \\
\text { the } \\
\text { appropriati } \\
\text { ons }(17 \%)\end{array}$ & $\begin{array}{l}\text { - Banking } \\
\text { system } \\
(14 \%)\end{array}$ & $\begin{array}{l}\text { - Financial Regulation and } \\
\text { infrastructure }(27 \%)\end{array}$ \\
\hline $\begin{array}{c}\text { Central } \\
\text { Bank of } \\
\text { South } \\
\text { Africa }\end{array}$ & $\begin{array}{l}\text { Semi- } \\
\text { annual }\end{array}$ & $\begin{array}{l}\text { - Outline } \\
\text { (3\%) }\end{array}$ & $\begin{array}{c}\text { - Macro } \\
\text { Developmen } \\
\text { t financial } \\
\text { international } \\
(22 \%)\end{array}$ & $\begin{array}{l}\text { Prudential } \\
\text { macro } \\
\text { Analysis } \\
\text { domestica } \\
\text { tes }(38 \%)\end{array}$ & $\begin{array}{c}\text { - Financial } \\
\text { Infrastruct } \\
\text { ure and } \\
\text { regulation } \\
(16 \%)\end{array}$ & & & \\
\hline
\end{tabular}

Source: developed nations (Bank for international settlement (BIS, 2006)) and emergent countries (sites of the central banks)

On the organizational level, the majority of the FSR are structured in order to analyze the whole of these sources of vulnerability by adopting a definite plan either in sectorial term or in term of risk. The RSF of the sectorial type, analyze in a separate way each sector and market in order to determine the various risks and the possible interactions being able to induce a systemic risk. On the other hand, the FSR structured in terms of risk are delayed on the most important risks and describe their level and their impact in the event of materialization.

The structure of the financial stability report is heterogeneous because of specificities of the economies and the financial systems of each country. Some are focused more on the banking system, as it is the case of the Bank of Spain, Bank of France and Riksbank in particular because of the importance of the banking system in the financing of the economy. On the other hand, other central banks also integrate the other types of financial institutions such as the Bank of England, the ECB, Bundesbank and the Central Bank of Singapore. With regard to other dimensions to be analyzed on the level of the report/ratio of financial stability (macroeconomic conditions, markets of capital and infrastructures), the whole of the central banks integrate them in a regular way.

On the basis of this analysis of the structures of the FSR of the central banks, it is recommended to adopt a sectorial approach. The report will have to thus contain an analysis of the main components of the financial system, the risks most projecting and possibly of the principal transmission channels of shocks. Thus, the financial stability report could be structured in the following way:

1. Highlight: it summarizes the whole of the results and analyzes transcribed in the report and makes it possible to give a comprehensive view on the risks weighing on financial stability. Following the example other central banks, this chapter will have to comprise a graph in cobweb (risk map) describing the evolution of the economic and financial vulnerabilities weighing on the financial system.

2. Chapter I "macro-financial Environment": this chapter describes the evolution of the economic conditions and financial developed nations and emergent. It is a question of following the principal economies, in particular Europe and the USA, through the principal macroeconomic aggregates (growth, inflation, unemployment, etc...), to analyze macroeconomic and financial imbalances with the international level and to describe the various policies of the central large banks being able to affect national and international financial stability. This chapter also analyzes in a detailed way the evolution of the domestic macroeconomic conditions through the follow-up of the key macroeconomic aggregates, of which in particular the economic growth, unemployment, the external vulnerabilities, public finances especially on budgetary soutenability and the evolution of the public deficit.

3. Chapter II "real Sector": this chapter analyzes the economic conditions and financial firms and households through a rigorous follow-up their inheritances. This chapter 
approaches the sectors headlights of the economy in particular the real sector. With regard to the households, this chapter should allow a follow-up of the indicators of consumption, income, saving and appropriations. Being the firms, an analysis of their situations economic and financial should be carried out on the basis of several indicator of which in particular manufacturing output, the contribution of the sectors in the growth, the utilization ratio of the capacities to produce and evolution of clear creations of firms. Also, several other balance sheet indicators are to be analyzed in order to determine the evolution of the financial conditions of the firms, it acts; return on assets (ROA), return on equity (ROE), leverage ratio, coverage ratio, working capital ratio and evolution of the appropriations by typology.

4. Chapter 3 "Financial institutions, capital markets and financial infrastructure": it is delayed on the analysis of the financial system by treating the financial conditions (structure, development and efficiency) of each component of the financial system (banks, specialized financial institutions, reinsurance and insurance companies, pension funds and finally finance companies) and the principal risks (credit risk, risk of market, risk liquidity, risk profitability and risk solvency) heavy on this last. The first part will have to relate to the banking system and the other finance companies through the follow-up of a panoply of indicators of which in particular the structure of the assets and banking liabilities and decomposition of the account of the products and charges. With regard to the other financial institutions, except field of supervision of the central banks (pension fund and reinsurance, insurance companies), the analysis is founded on the follow-up of the charges, the incomes, the premium accounts issued by category of insurance and of the liabilities and assets. The second part, constituting the core of the report/ratio, is interested in the principal risks weighing on financial stability. This chapter analyzes also the market evolution stock-brokers, bond-holders and of exchange through several indicators of which in particular those relating to the outputs, the procurement processes and of sale, to volumes of the transactions and volatilities. Have regard to the importance of the financial infrastructure in the maintenance of the solidity and the efficiency of the Moroccan financial system, a last section of this chapter should be devoted to the exhibition of the evolutions in term of legislation and term of technology of the financial platform relating to the systems of payment, of payment and netting. For this reason, various indicators can be used like: the number of transactions day laborers, the number of electronic charts in circulation, the number of systems of payment E-trade, etc.

5. Chapter 4 "Stress-test of the banking system": this chapter evaluates the degree of solidity of banking system on the basis of micro and macro stress tests. After the identification of the vulnerabilities or risks weighing on financial stability, the stresses tests banking and the macro stress tests will allow to formulate a judgment on the degree of impact strength of the financial system.

6. Appendices: this part is devoted to specific questions having for objective to facilitate the comprehension of analyzes carried out in the heart of the report. The Central banks use this part in heterogeneous ways; there are of them those which present the last evolutions financial regulation. Other Central banks devote this part to the items of research, prepared by economists of the Bank or external authors, on questions related to financial stability.

The structure suggested analyzes the whole of the components of the financial system and makes it possible to formulate a total judgment on the situation of financial system. However, it has to evolve/move according to the economic conditions and financial. Also, the Bank will be able to be focused in a forthcoming stage on particular components or specific risks. 
In addition, the financial stability report of a central bank must imperatively respect some basic principles. First of all, it must make it possible to the reader to determine the systemic risks through a clear analysis and an articulation of the various parts of the report. Also, the structure of the FSR must be standardized in order to facilitate to the final reader the follow-up of the situation of the financial system and the judgments of the monetary authorities. With regard to the other characteristics of the report to knowing its frequency and its availability, following the example majority of the central banks, it would be convenient to adopt a semiannual publication and to be committed on a time-table of diffusion in order to allowing a better regularity in the publication of the FSR. The central bank should devote a distinct heading on its official site for the communications as regards financial stability in order to avoid any overlapping with its other missions. The publication should relate to at the same time the FSR and the data used, except for those in confidential matter (like the individual data).

\section{WHICH INDICATORS TO USE?}

The indicators used within the framework of the RSF result from the macroeconomic and micro-prudential analysis and aim at covering dimensions having milked with financial stability. Indeed, the macroeconomic indicators, used in the report on the monetary policy, are included in the FSR in order to identify the areas of vulnerability and to describe the risks weighing on the stability of the financial system. In the same way, the micro-prudential indicators, employees in the reports of supervision, are often included in the FSR in order to evaluate the systemic and no-individual aspects.

Since the Nineties, where first missions FSAP (Financial System Assessment Program) were initiated, the IMF proposed, in answer for the purposes of the banking crises of the Eighties and Nineties, of the indicators of financial solidity (Financial Soundness Indicators, FSI) capable to approach the financial risks and banking weighing on financial stability. Initially, the IMF recommended to follow basic indicators (Core Indicators) including/understanding the statistics on quality, the solvency and the performance of the institutions of deposits and in the second time, to widen the device of follow-up to other advanced indicators (encouraged indicators) including specific data on the institutions of deposits, the households, not financial firms, the nonbanking markets and financial institutions.

On the same register, the ECB proposed in 2005 an alternative approach based on macroprudential indicators (Macro Prudential Indicators, MPI) in order to evaluate financial stability as a whole. Compared to the indicators of the IMF, the indicators proposed by the ECB are more numerous and make it possible to follow several components of the financial and economic system (Mörttinen and Al (2006)). Nevertheless, put besides some marginal differences, the two approaches use overall the same indicators of risk.

Except the Euro area which uses its own macro-prudential indicators, the majority of the countries use the standard approach of the IMF. Indeed, the central banks publish in the RSF on average 53\% of "Core" FSI gathering the indicators of solvency, of quality of the assets, profitability, liquidity and market. Although the indicators of solvency, quality of the assets and profitability practically appear in all the RSF, those relating to the liquidity and the market risk are not frequently used. With regard to the advanced indicators, the FSR employ between 37\% and $40 \%$. Being the indicators treating of the nonbanking financial institutions the FSR use between $14 \%$ and $20 \%$ of the indicators proposed by the IMF (Haan and Al (2006)).

Simultaneously with the indicators of financial solidity, other specific indicators are used to describe the tensions on the markets of capital. The objective is to extract the relative 
information with the risk contained in the financial assets, in particular the shares, the obligations and the options. Among these indicators appears: the volatility of the shares, the distance to the default, probability of default, the yield of sovereign bonds, the CDS premium, indicators of implicit volatility derived from the options and other derivative products.

In the same way, the central banks use other information, in quantitative and qualitative matter, resulting from the credit rating agencies, early warning systems or of the opinion polls on the financial system and its infrastructure. Indeed, many FSR bring back the last ratings of the financial institutions issued by Moody' S, S\&P and Fitch while insisting on the systemic securities of this notation. These notes make it possible to have an evaluation independent of the financial health of the institutions. In the same way, certain FSR restore the results of opinion polls in relation to the financial system, in particular the opinion of the actors of the financial market on the extent of the risks to which they are exposed and the investigation into the evolutions of the bank credit.

In the light of Benchmark, it arises that the central banks use overall the indicators proposed by the IMF and enrich them by other indicators suitable for inform about important dimensions as regards stability of the financial system. The indicators of risk, developed until now by the central banks, are overall on line with the practices of the central banks and the IMF. However, it is to be stressed that the relevance of the FSR does not depend solely on the quantity of indicators used, but rather of the quality of the analysis which the latter make it possible to offer. In this respect, the example of the Bank of England is interesting. Indeed, the report/ratio of BoE is composed of a panoply of economic indicators and financial covering the whole of the components of the financial system and economic. In addition to the indicators of financial solidity suggested by the IMF, other indicators the complementary such as CD sovereigns and banking, the raw material costs, the curve of the rates, the spreads of interest rate, implicit volatilities of the financial assets and the sovereign notations are used.

\section{WHICH IS THE PLACE OF THE MACRO STRESS TESTS IN THE FSR?}

The tests of resilience (stress tests) became essential analytical tools in the analysis and the evaluation of financial stability. They are used to measure the impact of an extreme and plausible shock on an institution or the financial system as a whole. These tools were used for the first time by the authorities of supervision on the level of the reports/ratios on the finance companies in order to evaluate the individual risks of the banking institutions and to formulate a judgment on the robustness of each institution.

As from the Nineties and in first programs F.S.A.P, a new approach of stress test was adopted, they are the macroeconomic stress tests or the macro stresses tests. The latter make it possible to quantify the relation between the macroeconomic conditions and the evolution of the performance, the solvency and the liquidity of the individual institutions and the banking system and financier as a whole (macro-financial linkages). They thus make it possible to provide a comprehensive framework of discussion on the macroeconomic risks incurred by the financial system and to measure the impact of it, in the event of materialization, on its impact strength.

Two approaches of macro stress test are used at the level them FSR in order to quantify the impact of the macroeconomic conditions on financial equilibrium. The first approach consists in identifying the plausible shocks and extremes which can affect the financial system and ask the financial institutions to lead them on the basis of their own internal model (Bottom-up approach). The second approach is based on an internal design of the macro stresses tests: within this framework, the Central banks use their own tools to evaluate the robustness of the 
financial system as for the macroeconomic shocks (approach Top-down). In the facts, and although the central banks often choose to adopt an approach Top-down with the detriment of the Bottom-up approach a stepping of the results of both approaches is necessary to arrive at relevant conclusions.

The exercise of macro stress test within the framework of the approach Signal-down proceeds in 5 stages: determination of the initial shocks, the simulation of the macroeconomic conditions by taking account of the shocks, identification of the banking wallet to stress, the modeling of the relation between fundamental macroeconomic and financial ones and the formulation of a judgment as for the solidity of the banking sector

After does the identification of the scenarios to be used in the exercise of the macro stress test, it is necessary to determine the banking book to stress, act of the banking book or the market book? This choice is justified by the structure of the balance-sheet of the banking system and its sources of margin. Have regard to the role of the banking system in the financing of the economy and the preponderance of the wallet of credit, the credit risk collected all the attention of the central banks and the macro stresses tests of credit were used (Figure 4).

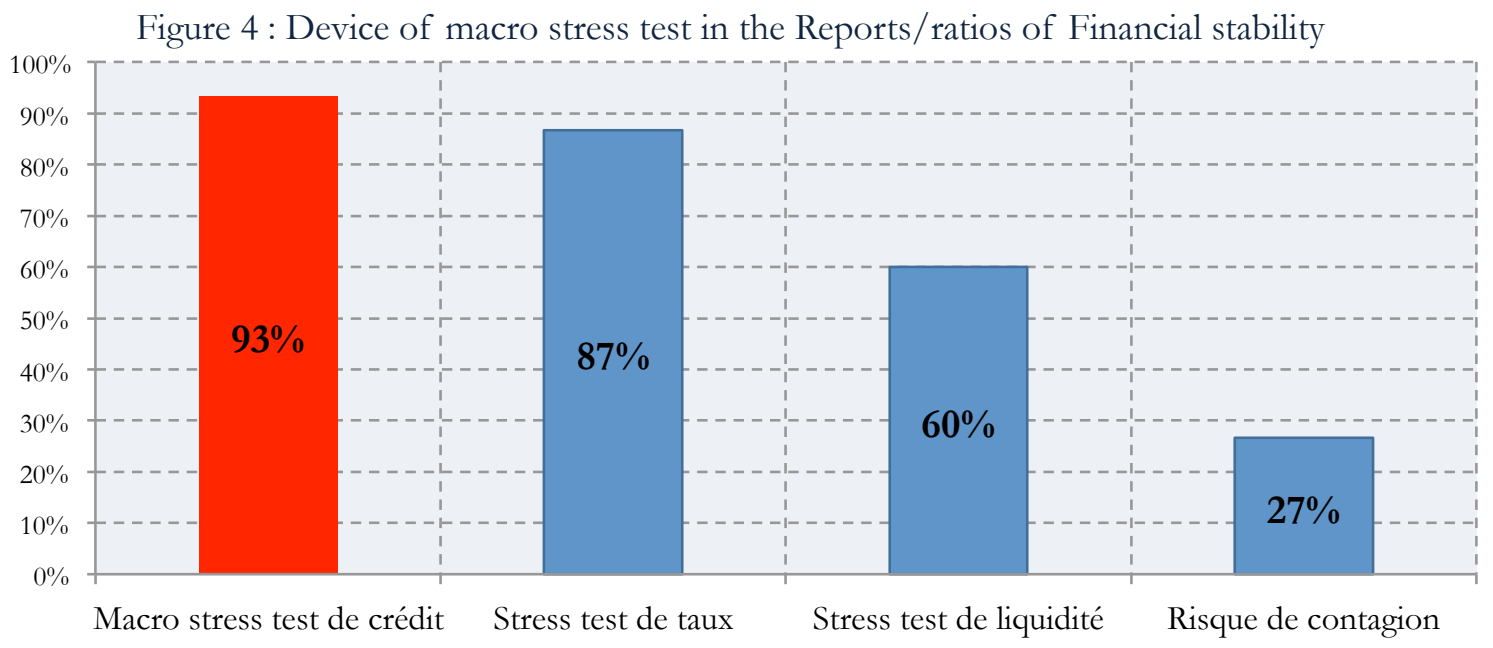

The macro stresses tests of credit are thus retained on the level of the RSF of the majority of the Central banks in order to describe the relation between the evolutions of the macroeconomic framework and the variables banking and financial. The models of systemic risk of credit are varied and the specifications retained by the Central banks depend on the characteristics of each country, of the level of development of the banking system and the nature of the available data (see Tableau 3).

Tableau 3 : devices of macro stress test of credit of the central banks communicated on the level of the RSF

\begin{tabular}{|c|c|c|c|c|}
\hline $\begin{array}{l}\text { Experiments } \\
\text { RSF }\end{array}$ & Endogenous variables & Model & $\begin{array}{c}\text { Methodology of } \\
\text { simulation of the scenarii }\end{array}$ & Variables of interest \\
\hline Chile & $\begin{array}{c}\text { Ratio of provisions, growth rate of the GDP, interest } \\
\text { rate and debt }\end{array}$ & $\begin{array}{l}\text { Time series } \\
\text { (VECM) }\end{array}$ & Model VECM & Solvency ratio \\
\hline Slovenia & NPL, interest rate, GDP and foreign exchange rate & (VECM) & Model VECM & Solvency ratio \\
\hline Czech & $\begin{array}{l}\text { New NonPowerful Loan (NPL), GDP, inflation and } \\
\text { interest rate }\end{array}$ & $\begin{array}{l}\text { Model of } \\
\text { Merton }\end{array}$ & macroeconomic model & Rate of defect \\
\hline Austria & $\begin{array}{l}\text { Rate of industrial defect, oil price, income available, } \\
\text { rate of inflation, export, industrial production and } \\
\text { interest rate }\end{array}$ & $\begin{array}{l}\text { (Regression } \\
\text { logistics) }\end{array}$ & Model VAR & $\begin{array}{l}\text { Distribution of the hoped } \\
\text { and unhoped-for Losses }\end{array}$ \\
\hline Belgium & Rate of defect of the firms, output gap, interest rate & $\begin{array}{c}\text { (Logistic } \\
\text { Regression) }\end{array}$ & $\begin{array}{l}\text { Macroeconomic model } \\
\text { NIGEM }\end{array}$ & $\begin{array}{l}\text { Rate of defect of the } \\
\text { firms }\end{array}$ \\
\hline
\end{tabular}




\begin{tabular}{cccc}
\hline Germany & $\begin{array}{c}\text { Logistic transformation of the rate of the provisions, } \\
\text { GDP, interest rate and growth of the appropriations }\end{array}$ & Data of panel & Macroeconomic model \\
ECB & $\begin{array}{c}\text { Frequency of the hoped defects, GDP, inflation, } \\
\text { assets price, foreign exchange rate and interest rate }\end{array}$ & $\begin{array}{c}\text { Satellite model } \\
\text { Provisions }\end{array}$ & $\begin{array}{c}\text { Model GVAR with several } \\
\text { Convention countries }\end{array}$ \\
France & Probability of change of notation, variables & Frequencies of the \\
macroeconomic & (Logistic & Model Mascot hoped \\
\hline
\end{tabular}

* This table was elaborate on the basis of FSR of the Central banks

The results of these models as well as the assumptions retained for the exercise of macro stress test are often communicated in the financial stability report. However, the practice of the Central banks shows clearly that the information communicated on the level of the parts dedicated to the macro stress test is varied and often depends on specificities of each country and the degree of transparency wished. Table 4 represents the information communicated by several Central banks within the framework of the macro stress test of credit.

Tableau 4 : Practices of macro stress of credit at some Central banks

\begin{tabular}{|c|c|c|c|c|}
\hline Central banks & Scenarios & Stressed risk factor & Percentage allocated in the FSR & Variables of interest \\
\hline $\begin{array}{c}\text { Central Bank } \\
\text { of Japan }\end{array}$ & $\begin{array}{l}\text { Two scenarios: basic and an } \\
\text { extreme scenario using a } \\
\text { model VAR }\end{array}$ & $\begin{array}{l}\text { Growth rate of the GDP, the } \\
\text { market index TOPIX, interest } \\
\text { rate of long run }\end{array}$ & $12 \%$ & Credit costs, Ratio Tier 1 \\
\hline $\begin{array}{l}\text { Central Bank } \\
\text { of England }\end{array}$ & $\begin{array}{c}\text { Two scenarios: basic and an } \\
\text { extreme scenario using a } \\
\text { model BVAR }\end{array}$ & $\begin{array}{l}\text { Growth rate of the GDP, price } \\
\text { index of the real assets, } \\
\text { unemployment rate, interest rate } \\
\text { of short and long terms }\end{array}$ & - & $\begin{array}{l}\text { Banking profit and } \\
\text { solvency ratio }\end{array}$ \\
\hline Bundesbank & $\begin{array}{l}\text { Two scenarios: basic and an } \\
\text { extreme scenario }\end{array}$ & $\begin{array}{l}\text { Growth rate of the GDP, interest } \\
\text { rate of short and long terms and } \\
\text { the curve of the rates }\end{array}$ & $8 \%$ & $\begin{array}{l}\text { Net interest margin, other } \\
\text { and ratio Tier } 1\end{array}$ \\
\hline $\begin{array}{c}\text { Czech Central } \\
\text { Bank }\end{array}$ & $\begin{array}{l}\text { Two scenarios: basic and an } \\
\text { extreme scenario (the } \\
\text { extreme scenario is divided } \\
\text { into three scenarios } \\
\text { alternate) by using the } \\
\text { forecasting models of the } \\
\text { Bank }\end{array}$ & $\begin{array}{c}\text { Growth rate of the GDP, } \\
\text { unemployment rate, foreign } \\
\text { exchange rate and interest rate } \\
\text { at one year }\end{array}$ & $7 \%$ & $\begin{array}{c}\text { Amounts receivable in } \\
\text { suffering and the solvency } \\
\text { ratio }\end{array}$ \\
\hline $\begin{array}{c}\text { Central Bank } \\
\text { of Brazil }\end{array}$ & An extreme scenario & $\begin{array}{l}\text { Growth rate of the GDP, interest } \\
\text { rate and foreign exchange rate }\end{array}$ & $2 \%$ & $\begin{array}{l}\text { Amounts receivable in } \\
\text { suffering and the solvency } \\
\text { ratio }\end{array}$ \\
\hline $\begin{array}{c}\text { Central Bank } \\
\text { of India }\end{array}$ & $\begin{array}{l}\text { A basic scenario and three } \\
\text { scenarios unfavorable (weak, } \\
\text { average and extreme) based } \\
\text { on a historical approach }\end{array}$ & $\begin{array}{l}\text { Interest rate of short term, rate } \\
\text { of inflation, ratio of exports } \\
\text { with the GDP and rate of } \\
\text { inflation }\end{array}$ & $3 \%$ & $\begin{array}{c}\text { Amounts receivable in } \\
\text { suffering and the solvency } \\
\text { ratio }\end{array}$ \\
\hline $\begin{array}{c}\text { Central Bank } \\
\text { of Hungary }\end{array}$ & $\begin{array}{l}\text { Two scenarios: basic and an } \\
\text { extreme scenario }\end{array}$ & $\begin{array}{l}\text { Growth rate of the GDP, real } \\
\text { Foreign exchange rates, Spread } \\
\text { CD, Unemployment rates, } \\
\text { Assets prices }\end{array}$ & $7 \%$ & $\begin{array}{l}\text { Losses on amounts } \\
\text { receivable and solvency } \\
\text { ratio }\end{array}$ \\
\hline $\begin{array}{l}\text { Central Bank } \\
\text { of Sweden }\end{array}$ & $\begin{array}{l}\text { Two scenarios: basic and an } \\
\text { extreme scenario resulting } \\
\text { from the scenarios used by } \\
\text { the European Banking } \\
\text { Authority (EBA) }\end{array}$ & $\begin{array}{l}\text { Growth rate of the GDP and } \\
\text { interest rate }\end{array}$ & $4 \%$ & Profit and solvency ratio \\
\hline
\end{tabular}

The international experiment shows thus that the losses on amounts receivable and the solvency ratios are often used, as variable of answer, to evaluate the stability of the banking system, following the advent of macroeconomic shocks. Moreover, the part allocated with the macro stresses tests in the RSF is between 2 and $12 \%$ of the aforesaid reports/ratios, without taking account of framed and the appendices which contain in the majority of the cases of the items of research and the notes detailing the systemic models of risks used within the framework of the macro stress test. 
As regards communication, the results of the macro stresses tests can be paid in an aggregate or granular way. The countries choosing more transparency choose to give information by bank or segment of banks (Latvia, Brazil, Spain and the United States). These central banks consider that the diffusion of sensitive information is certainly suitable for induce financial instability, nevertheless, it can on the contrary encourage the establishments with more a greatest caution and push the central bank to improve its decision making and thus to reinforce its independence and its credibility.

Currently the majority of the Banks have a device of stress test and macro stress test aligned on the international standards. Indeed, the systemic models of risks of credit and profitability will make it possible to ensure a rather satisfactory communication as regards macro stress test. In the same way, with the level of the micro stress tests the central banks have a framework of stress test of liquidity and rather advanced interest rate thus making it possible to formulate a judgment on the degree of sensitivity of the Moroccan banks an evolution of interest rates or a change in the behaviors of the depositors.

\section{CONCLUSION}

The widening of the missions of the central banks to the maintenance of stability requires an effective communication strategy making it possible to anchor anticipations of the agents and to sensitize them as for the risks incurred by the financial system. This strategy will have to inform and reassure the public as for the areas of vulnerabilities and with the macroprudential policies to implement, in order to limit the systemic risks.

The FSR is the principal channel of communication as regards financial stability. Its production as its structure are conditioned by several elements, namely, the maturity of the framework analytical, the structure of the financial system and the international level of integration at financial market and economic system. The practices of the central banks on the matter are heterogeneous and it seems difficult to reach a consensus from them. Certain very advanced report are interested in the unit of the components of the financial system and economic whereas others are limited to some components of the financial system, in particular, the banking system.

The analysis carried out in this work shows that the majority of the countries articulate their report around five great parts: (I) macro-financial environment, (II) the real sector, (III) financial intermediaries, markets of capital and infrastructures, (iv) the stresses test and macro stress test and ( $\mathrm{v}$ ) items and documents of research. The first three parts are intended to describe and identify the economic and financial vulnerabilities incurred by the financial system. The fourth part evaluates the impact strength of the financial system in the event of materialization of the possible hazards. Lastly, the last part, of general order, is intended to produce and share some reflections on problems related to financial stability.

As regards indicators to be communicated on the level of the FSR, the central bank could be limited to the indicators suggested by the IMF and some indicators resulting from the markets of capital. Most important is to use indicators allowing to give an overall assessment of each component of the financial system and to facilitate the evaluation of the transverse risks. With regard to the stresses tests and macro stress tests, the banks can communicate the results on the banking system in an aggregate way in order to reassure the public as for the impact strength of the financial system. 


\section{References}

1. Irving Fisher Committee, (2005), "Data Requirements for Analyzing the Stability and Vulnerability of Mature Financial System", BIS.

2. Jim Wilkinson, Kenneth Spong, and Jon Christensson, 2010 "Financial Stability Reports How Useful During a Financial Crisis?" Economic Review (Federal Reserve Bank of Kansas City).

3. Jon Christensson, Kenneth Spong, and Jim Wilkinsonon, December 2010. "What Can Financial Stability Reports Tell Us about Macro prudential Supervision?" Research Working Paper No 15. (Federal Reserve Bank of Kansas City).

4. Houben, A., J. Kakes and G. Schinasi, 2004, Towards a Framework for Financial Stability, Occasional Study No. 2(1), (Nederlandsche Bank).

5. Lastra, Rosa Maria "How much accountability for central banks and supervisors?" Central Banking (2001), Vol.12 (2).

6. Martin Čihák, June 2006. “How Do Central Banks Write on Financial Stability?”, Working Paper No. 163, (IMF).

7. Martin Čihák, Sònia Muñoz, Shakira Teh Sharifuddin, and Kalin Tintchev, January 2012. "Financial Stability Reports: What Are They Good For? (IMF), Working Paper No 1, (IMF).

1. Financial stability report, 2012 (Swiss National Bank).

2. Financial stability report in the world (GFSR, 2012 (the IMF)).

3. Financial stability report (ECB, 2011).

4. Financial stability Review, 2012 (Central Bank of Luxembourg).

5. Financial stability report, June 2012, (Bank of England).

6. Financial stability report, 2012, (Riksbank, Banks National of Sweden).

7. Financial stability report, (Nederlandsche Bank, Banks National of the Netherlands).

8. Financial stability report, November 2012 (National Bank of Spain).

9. Financial stability report, 2012, (Norges Bank, Banks National of Norway).

10. Sander Oosterloo, Jakob de Haan, Richard Jong-A-Pin, (2006), "Financial stability reviews: A first empirical analysis", Journal of Financial Stability. 